\title{
The Quinean Roots of Lewis's Humeanism
}

DOI:

10.1093/monist/onx007

\section{Document Version}

Accepted author manuscript

Link to publication record in Manchester Research Explorer

\section{Citation for published version (APA):}

Janssen-Lauret, F. (2017). The Quinean Roots of Lewis's Humeanism. The Monist, 100(2), 249-265.

https://doi.org/10.1093/monist/onx007

\section{Published in:}

The Monist

\section{Citing this paper}

Please note that where the full-text provided on Manchester Research Explorer is the Author Accepted Manuscript or Proof version this may differ from the final Published version. If citing, it is advised that you check and use the publisher's definitive version.

\section{General rights}

Copyright and moral rights for the publications made accessible in the Research Explorer are retained by the authors and/or other copyright owners and it is a condition of accessing publications that users recognise and abide by the legal requirements associated with these rights.

\section{Takedown policy}

If you believe that this document breaches copyright please refer to the University of Manchester's Takedown Procedures [http://man.ac.uk/04Y6Bo] or contact uml.scholarlycommunications@manchester.ac.uk providing relevant details, so we can investigate your claim.

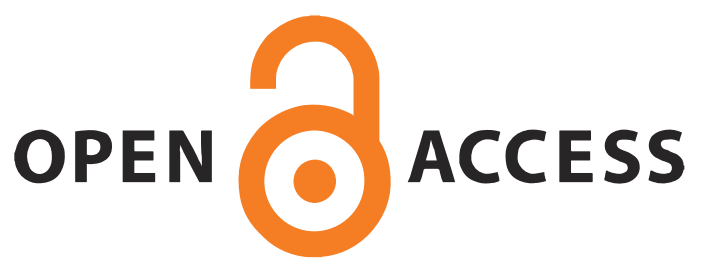




\title{
THE QUINEAN ROOTS OF LEWIS'S HUMEANISM
}

\author{
FREDERIQUE JANSSEN-LAURET
}

\begin{abstract}
An odd dissensus between confident metaphysicians and neo-pragmatist antimetaphysicians pervades early twenty-first century analytic philosophy. Each faction is convinced their side has won the day, but both are mistaken about the philosophical legacy of the twentieth century. More historical awareness is needed to overcome the current dissensus. Lewis and his possible-world system are lionised by metaphysicians; Quine's pragmatist scruples about heavy-duty metaphysics inspire anti-metaphysicians. But Lewis developed his system under the influence of his teacher Quine, inheriting from him his empiricism, his physicalism, his meta-ontology, and, I will show in this paper, also his Humeanism. Using published as well as never-before-seen unpublished sources, I will make apparent that both heavy-duty metaphysicians and neo-pragmatist anti-metaphysicians are wrong about the roles Quine and Lewis played in the development of twentieth-century philosophy. The two are much more alike than is commonly supposed, and Quine much more instrumental to the pedigree of current metaphysics.
\end{abstract}

\section{Introduction: Quine and His Student Lewis from a Historical Point of VIEW}

Metaphysical enquiry into the existence and nature of things, pronounced dead midcentury by logical positivists, late Wittgensteinians, ordinary-language philosophers, and pragmatists, took centre stage again at the end of the twentieth and the beginning of the twenty-first century. Champions of metaphysics consider its victory complete, holding up David Lewis (1941-2001) as their hero. His pluriverse of possible worlds, they say, made metaphysics respectable once again. But anti-metaphysicians, inspired by W.V. Quine's (1908-2000) pragmatist scruples about heavy-duty metaphysics, proclaim with equal confidence that metaphysics has no legitimacy. All of this is peculiar when we consider the two philosophers' personal and intellectual history. Quine was Lewis's teacher, and there was much common ground between them. Both were empiricists, physicalists, Humeans, lovers of ontological desert landscapes who made efforts to explain away or reduce abstruse posits naturalistically.

Increased historical awareness of twentieth-century developments would reveal the true import of Quine's and Lewis's work, and so help overcome such pervasive misunderstandings between metaphysicians and anti-metaphysicians. To bring about a historically selfaware metaphysics we must extend the boundaries of the history of analytic philosophy to include the mid-to-late twentieth century. Analytic philosophy's early beginnings, its revolutionary overthrow of idealism and bold investigation of how language maps onto an external world, have been subjected to close historical scrutiny. Now, in the twenty-first century, 
we can investigate its development between 1945 and 2000 with the benefit of hindsight, too. But an even more compelling reason to develop this new subfield, the recent history of analytic philosophy, is because we twenty-first century philosophers need it to remove misconceptions about our intellectual heritage. Quine in particular is a sadly misunderstood figure, despite his stature. His intellectual relationship with his unabashedly metaphysical disciple Lewis is an especially illustrative case in point. My overarching project is to set the record straight about Quine's role in metaphysics' rumoured demise, and its improbable rise from its ashes, between the mid- and late twentieth century. Quine, I argue, was not an anti-metaphysician or flat-footed deflationist, but an interesting, empiricist metaphysician, striving to fit metaphysics around scientific discovery. ${ }^{1}$ In the service of that larger project, this paper teases out one strain of unacknowledged Quinean influence on Lewis: his Humeanism.

First I will briefly rehearse the case that Quine always was a metaphysician. Quine's views developed over time, but a preference for a modest, empirically-based kind of metaphysics is a constant presence throughout his early, middle, and late periods. His empiricism and pragmatism led him to deny the legitimacy of Aristotelian and a priori metaphysics. These he viewed as ontologically extravagant, indefensible additions to the frugal physicalism he favoured. Still, to embrace a frugal, physicalist ontology is to endorse a metaphysical point of view. Secondly, I will present historical evidence, based on a combination of published works and never-before-seen unpublished papers and correspondence, which suggests that Lewis's Humean metaphysics derives, not from his reading Hume, but most likely from Quine. Thirdly, I will show that Lewis's mature, Humean counterpart theory, too, has thoroughly Quinean underpinnings.

\section{W.V. Quine: Empiricist MEtaphysician}

Anti-metaphysical pragmatists and inferentialists denounce metaphysical discourse as empty. It derives, they say, from mistaking merely useful or conventional features of our discourse for profound truth about reality. Some prominent anti-metaphysicians of this stripe claim Quine as one of their own: 'Quine, too, is really a deflationist about ontological issues' (Price 2009: 325). It is true that Quine viewed many of the darlings of current metaphysics with deep suspicion. He refused to countenance possibilia, properties, fictional characters, mathematical entities not quantified over in physics, and propositions. It is also true that his opposition to such posits was motivated at least in part by his pragmatist take on philosophy of science and epistemology. But Quine never endorsed the neo-pragmatists' view that metaphysics is no more than the result of a forced, artificial separation between true and merely useful discourse. His pragmatism was epistemological, not the kind which identifies usefulness with truth.

The anti-metaphysical interpretation of Quine results from an ahistorical approach to his work. When we, twenty-first century philosophers, read 'On What There Is' or 'Two Dogmas of Empiricism', or perhaps 'On Carnap's Views on Ontology' out of context, we find individual lines which sound deflationist or anti-metaphysical. Read in this way, early

\footnotetext{
${ }^{1}$ See Janssen-Lauret 2015, Janssen-Lauret 2016, and MacBride and Janssen-Lauret 2015.
} 
Quine is easily mistaken for an anti-metaphysical deflationist, but that does not mean that he was one. The young Quine framed his work in these terms because his main interlocutor at the time was his anti-metaphysical mentor Carnap. As a result, the papers are shot through with vestigial Carnapian vocabulary. But that does not equal an endorsement of Carnap's anti-metaphysical views. On the contrary, Quine deploys the vocabulary in order to deftly rebut such views. He sounds Carnapian when, for instance, he states that metaphysical statements follow trivially from our conceptual schemes (1948: 29) and that ontological questions are questions 'not of fact but of choosing ... a convenient framework for science' (1951a: 72). But contra Carnap, whose principle of tolerance claims that different conceptual schemes are incommensurate, Quine maintains that schemes certainly can be compared to each other 'in point of real explanatory power' (1948: 30). Ontologically profligate schemes positing properties or meanings are inferior, says Quine, because they add entities without adding explanatory value (1948: 31). Apparently agreeing with Carnap that ontology is a matter of framework choice, Quine immediately qualifies this claim in a way which ultimately undermines it. He invokes his semantic holism to overthrow Carnap's distinction between scientific questions of fact and pragmatic questions of framework choice, concluding 'I agree [with Carnap] only if the same be conceded for every scientific hypothesis' (1951a: 72). According to Quine, ontology is continuous with science, not separate from it. Scientific and ontological questions are equally answerable.

Historically ill-informed readings of Quine are so common because historical scholarship on him, and on the mid-twentieth century generally, is only just beginning to emerge. Until now only a small amount of historical work has been carried out on the general development of analytic philosophy after the 1930s. Authors who touch upon Quine's role within it correctly credit him with making room for metaphysics after positivism, but generally very briefly and without making a sustained case for a pro-metaphysical interpretation of Quine (Simons 2013: 713-725, Williamson 2014: 12, Moore 2012: 318-323). Specifically Quine-focused historical work is well-informed about the evolution of Quine's thought, including his metaphysics, but concentrates (with some exceptions, e.g. Hylton 2007) almost exclusively on his early work from the 1940s and early '50s (Ben-Menahem 2005, Mancosu 2008, Frost-Arnold 2013), or on the young Quine's relationship with Carnap (Creath 1990). What is needed to rebut the anti-metaphysical interpretation of Quine and come to a historically sound appreciation of recent developments in metaphysics, is detailed historical work which shows continuity between the early Quine and Quine in his prime, viewed in his historical context, the 1960s and '70s. In this paper, I continue this work (begun in Janssen-Lauret 2015). It is Quine's mature works, including his magnum opus Word and Object, that show him at work as a metaphysician, and in dialogue with great philosophers other than Carnap, such as Barcan Marcus, Strawson, and later Davidson and Lewis.

Quine's penchant for the metaphysical is apparent from his earliest publications. Witness, for instance, the title of his 1934 paper 'Ontological Remarks on the Propositional Calculus', which takes issue with what he describes as the Fregean-Wittgensteinian assumption that sentence letters stand for objects. His criterion of ontological commitment-'to be is to be the value of a variable' - usually dated to 'On What There Is', first appears in 
print in the late '30s (1939: 708). Why, then, is Quine so often misunderstood as antimetaphysical? One part of the story ${ }^{2}$ is that Quine's criterion of ontological commitment is often taken as a deflationist edict or a materialist call to arms, inviting us to formalise physics and count its variables. That would be a significant and not unphilosophical task for a philosopher of physics to undertake, but it is not a task imposed by Quinean ontological commitment. Though naturalistically oriented, Quinean ontological commitment is neither physicalist nor deflationist. It does not dictate any ontology. Quine's criterion is a meta-ontological tool, providing a strategy for determining what is assumed to exist by candidates for an overall best theory. Rather than recommend some particular ontology, it is designed to compare and adjudicate between rival theories (Janssen-Lauret 2016: 584-586). Quine aimed to put the existence claims of philosophy on an equal footing with those of the natural sciences. Existence claims made in scientific theories are warranted just in case they are indispensable to an overall best theory. A naturalistic philosopher, who seeks a philosophy continuous with empirical and theoretical science, similarly has good reason to believe in objects which are mentioned in the fullest, clearest statement of her best theory. But the criterion of ontological commitment does not identify a single best theory. It does not prescribe that it must be, or even include, physics.

Quine himself strove to maintain a physicalist ontology throughout his career, driven by a longing for parsimony to an extent motivated by pragmatism. Yet his pragmatism did not imply deflationism about truth or ontology. Quine's stated reasons for his distrust of abstracta are sometimes pragmatist, but never venture close to a Carnapian pragmatist line according to which metaphysical questions are pseudoproblems, an artificial wedge we drive between truth and utility. Even in the '30s, when Quine was still deeply in thrall to Carnap, he disavowed that line. 'We are tempted at this point to dismiss the whole issue between nominalism and realism as a metaphysical pseudoproblem. But in thus cutting the Gordian knot we cut too deep' (1939: 704). Instead he recommended engaging in metaphysics of a kind tempered by empirical enquiry: 'the ontological question transcends linguistic convention: How economical an ontology can we achieve and still have a language adequate to all purposes of science? In this form the question of the ontological presuppositions of science survives.' (1976 [1939]: 201).

Where the young Quine opposed some specific array of abstract posits - possibilia, propositions, attributes - he generally claimed to do so because to posit them would conflict with his other metaphysical commitments. His argument against the posits of modal logic was initially that they do not fit within a physicalist ontology: 'the contemplated version of quantified modal logic is committed to an ontology which repudiates material objects (such as the Evening Star properly so-called) and leaves only multiplicities of distinct objects (perhaps the Evening Star concept, the Morning Star concept, etc.) in their place' (1947: 47). (Incidentally, Quine's statement here is true of Carnap's modal logic, but not of that of his paper's main target, Ruth Barcan. Barcan was an avowed nominalist who treated her quantified modal logic as a syntactic calculus, not a possible-world system (Barcan

\footnotetext{
${ }^{2}$ Another part of the story may be that Quine's thesis of the inscrutability of reference is mistaken for an expression of deflationism (Janssen-Lauret 2015: 154).
} 
1947, Barcan Marcus 1978).) $)^{3}$ Against properties and propositions Quine adduced similar objections, holding out hope for their indispensability to physical science: 'nominalism can be formulated thus: it is possible to set up a nominalistic language in which all of natural science can be expressed' (1939: 708). Quine can be seen, then, to make negative existential claims which are not pseudo-statements, but inferred from their incompatibility with positive existential claims he asserts. In other words, he took himself, in demurring from positing possibilia, propositions, and attributes, to be doing metaphysics - specifically, ontology. So his distaste for abstract objects did not flow from, or imply, a global antimetaphysical view. It is also noteworthy that the later Quine began to assert the existence of numbers under theoretical pressure from physics. A proper neo-pragmatist ought not to answer a pseudo-question first with a tentative 'no', then with a firm 'yes'. Negations of pseudo-statements are also pseudo-statements, and just as unanswerable. Quine was sceptical of some of the central posits and questions of 'traditional metaphysics' (1951a: 66) - God and God's nature, universals and their natures, the soul and its nature - but also repeatedly affirmed that his usage of 'ontology' accords with 'some portion of philosophical tradition' (1951b: 13; see also 1951a: 66). Metaphysics à la Quine is a modest, a posteriori, frugal exercise in living within our means. Its posits are those which match our best scientific theories. Still, a frugal, empiricist ontology is an ontology. To endorse one is to take a metaphysical stance on what there is. Quine clearly took questions of what categories of things exist - and how they are related to each other - to be legitimate and answerable. He was also happy to admit empirically well-informed answers to some traditional metaphysical questions in areas other than ontology. He advocated, for instance, a Humean account of causation (1974: 5-8), a four-dimensionalist account of time and persistence (1960: 170-176), and a reductive account of mind and body (1960: 264-267).

Quine never endorsed a version of pragmatism which identifies usefulness with truth. His pragmatism was, rather, epistemological, taking usefulness as a guide to truth. Pragmatism is what leads us to decide to hold true one theory, along with its imputations of existence, in preference to other theories because it has served us better than any other, and not led us astray. The fact that the theory has served us well so far is a good, though fallible, reason to believe that it has the best chance out of any theory we've so far entertained of being true. As a result, its imputations of existence are the most likely to map onto the real constituents of the world. According to Price, although Quine 'take[s] for granted that language has a well-defined core descriptive function ... given Quine's own minimalism about truth, it is no use his saying that descriptive discourse aims at truth' (2009: 334). But Price is wrong; Quine never subscribed to minimalism. He was perfectly within his rights to say that science pursues, rather than decrees, truth (1990: 67). Quine embraced Tarski's disquotationalism about truth, but not the minimalist thesis that description can be explained in purely disquotational terms, without appeal to worldly referents and satisfaction. What he objected to in traditional theories of truth was their positing of senses and propositions, not their reliance on values of variables which satisfy, or fail to satisfy, the predicates ascribed to them. As Quine put it: 'the general task which science sets itself

\footnotetext{
${ }^{3}$ For further details, see Janssen-Lauret 2015: 158-161.
} 
is that of specifying how reality 'really' is: the task of delineating the structure of reality as distinct from the structure of one or another traditional language (except, of course, when the science happens to be grammar itself). The notion of reality independent of language is carried over by the scientist from his earliest impressions, but the facile reification of linguistic features is avoided or minimised' (Quine 1957: 5). Quine's epistemological pragmatism does not imply ontological deflationism. According to him usefulness is not truth, but a reliable indicator of truth. Truth itself is a matter of correct representation of an external world about whose nature and denizens we can fruitfully theorise. So neither Quine specifically, nor pragmatists and empiricists generally, need deny the legitimacy of metaphysics.

Certain things which go by the name of metaphysics are impossible to square with Quinean empiricism and epistemological pragmatism. A prime example is a priori metaphysics based on first philosophy. When Hylton, for example, contends that Quine is opposed to traditional metaphysics (2007: 363), he takes for granted that traditional metaphysics is a priori - though Hylton acknowledges that not all metaphysics is. Another is the kind of metaphysics which explicitly defines itself as being outside the scope of science, as in this characterisation by Rosen: 'a metaphysical claim is a substantive claim about some allegedly important aspect of reality that cannot be established or even substantially supported by the commonsensical and scientific methods we normally employ for adjudicating controversial claims about the world around us' (2013: 552-3). (Oddly, Rosen nevertheless classifies Quine as a moderate metaphysician, given his firm views on ontology, causation, physicalism and the like. Quine, of course, believes those views to be substantially supported by scientific methods.) But there is no need to characterise metaphysics as a priori or unsupported by science. According to Quine, metaphysics is just enquiry into ontology and ideology. If that's all Greek to you, a keen student of Quine's translated it into eight Anglo-Saxon monosyllables: 'what things there are and how they are'. That student was, of course, the renowned metaphysician David Lewis (1999: 206).

\section{Lewis's Humeanism: The Influence of Quine}

Lewis, intelligent and original philosopher though he was, did not spring fully formed from the head of Zeus. His views were influenced by a variety of equally intelligent and original philosophers he associated with. That Quine was a major, perhaps the major, influence upon Lewis and his metaphysics is something of which contemporary philosophers are insufficiently aware. In part this is due to the pervasive misconception that Quine was anti-metaphysical. Another factor is an equally pervasive misconception among presentday metaphysicians that Lewis was much more like them than he actually was. That second misconception, like the first, results from an ahistorical approach to twentiethcentury philosophy. Properly understood in his historical context, Lewis resembles Quine much more closely.

Twenty-first century metaphysicians prophesy a new heyday of a priori, rationalist first philosophy. While the natural sciences have their own empirical methods, and their own physical subject matter, they say, philosophers employ non-empirical, a priori methods 
to work out the structure of reality: what must be the case, what can be the case, and what sorts of things can possibly co-exist. Such modal facts about the structure of reality, metaphysical existence questions, and Aristotelian category questions are an entirely different kind of beast from, indeed 'nothing to do with', empirical existence questions (Tahko 2011: 28). Metaphysical results cannot be overthrown by any empirical results; empirical science must operate within the confines of a priori philosophy. The resurgence of metaphysics as first philosophy at this point in history is rather odd. A priori insight into the nature of what must and can be the case was problematised not just by Quine, but by Carnap, Wittgenstein, the Lvov-Warsaw School, and the Vienna Circle in the early twentieth century drawing upon developments in mathematics - Cantorian set theory - and physics - general relativity - which involved real scientific progress being made by overturning such accepted intuitive, a priori principles as 'nothing is the same size as its proper part' and Euclid's 'parallel lines never meet'. It is also odd that one of the great heroes of twenty-first century metaphysicians is Lewis, whose pluriverse of possible worlds they frequently invoke. Lewis was concerned to account for the literal truth of our claims about what can be the case and what must be the case by appealing to other, parallel, physical universes, distinct space-times and their inhabitants (Lewis 1986a). Something is possible if and only if it is the case in some such universe, and necessary if and only if it is the case in all of them. Modern metaphysicians rely upon possible-world discourse to justify their view that knowledge of possibility, necessity, and possible co-existence is not empirical, but to be settled independently in the thought laboratory (Lowe 2006: 5-6). Lewis never intended or approved of any such use of his modal philosophy.

Lewis's pluriverse arose from reflection upon and remained indebted to the empiricist system of his teacher Quine. Even the title of his magnum opus On the Plurality of Worlds occurs - probably as a tongue-in-cheek reference to Giordano Bruno - in an early work by Quine where he opposes the existence of a 'plurality of worlds' besides this one, some of which contain Pegasus (1944: 160-161, translation in Carnielli, Janssen-Lauret, and Pickering). Lewis, like Quine, was and always remained an empiricist, a physicalist, an ontological minimalist, someone who viewed the methods and subject matter of philosophy and the empirical sciences as continuous with each other, not as radically dissimilar. ${ }^{4}$ Central themes of Lewis's work have been deeply misunderstood because they are forcibly and incorrectly separated from their Quinean roots. Lewis's pluriverse at first sight appears ontologically profligate and anti-empiricist: how could we possibly know these objects exist by empirical investigation? Upon closer inspection, it turns out that it is both an exercise in Quinean ontology and bound by Quine's empiricist strictures. Its first appearance is as a translation of the possible-world talk Quine disparaged into Quine's preferred firstorder ontological idiom (Lewis 1968). Positing the pluriverse is justified by appeal to its

\footnotetext{
${ }^{4} \mathrm{My}$ concern here is with the influence of Quine to be found in Lewis's early writings in the '60s and '70s. In Lewis's later phase, beginning in the '80s, this influence appears watered down by Armstrong's persuading Lewis to countenance work for universals and to endorse the distinction between natural and non-natural properties. Yet to a large extent, those influences remained intact even then, and in his later works, especially 'Ramseyan Humility', Lewis returns to his Quinean roots, admitting naturalness does not ward off ontological relativity. (See MacBride and Janssen-Lauret, in development).
} 
theoretical fruitfulness, which Lewis, adhering to Quinean naturalism, took as a good reason to hold it true (1986a: 4). In Lewis's capable hands, possible worlds also furthered the highly Quinean project of attempting to reduce or explain away naturalistically suspect entities in physicalistically acceptable terms. Lewis scrupulously avoided the abstruse posits beloved of first philosophers. Instead, he constructed propositions, minds, causes, and, in his later period, sets all out of spatiotemporally extended possible universes which are just like ours. Much more could be said about each of these. But for reasons of space, my topic in this paper is Lewis's Leitmotif of Humeanism. This too, I will show, has deep Quinean roots.

Key to Lewis's system is the doctrine that things are entirely loose and separate, that there are no necessary connections between distinct objects. This doctrine goes by the name of 'Humeanism', and was indeed maintained by David Hume. Perhaps because of the name, it is easily assumed - if people reflect on the question at all - that Lewis came to this doctrine by reading Hume. The assumption appears reasonable; after all, Lewis also advocated a counterfactual theory of causation inspired by Hume's remark, in section VII of his Enquiry, that causation occurs where 'if the first object had not been, the second never had existed' (quoted in Lewis 1973: 556). But neither Lewis's publications nor his Nachlass $^{5}$ reveals any deep engagement with Hume elsewhere. Where Hume appears in the index of Lewis's collected papers, it is either in reference to that very same quotation from the Enquiry (1986b: 159, 161, 216), or where Hume's name comes up as a fairly arbitrarily chosen example, e.g. in the invented case of a mad person who believes himself to be Hume (1983: 141-154). Where his name occurs in On the Plurality of Worlds, Lewis either uses Hume as an example (of a space-time worm, 1986a: 210) or briefly ascribes Humeanism to him without citing his work (1986a: 87, 91, 181). Nor does any perusal of Lewis's correspondence, unpublished work, and student papers yield evidence that Lewis ever made a serious study of Hume beyond the undergraduate level.

A better hypothesis is that Lewis's counterfactual theory of causation was indeed derived from Hume, but his Humeanism developed independently, and came from Quine. Like all other philosophers educated in the Western, empiricist tradition, Lewis read Hume as an undergraduate, both at Swarthmore and as a visiting student at Oxford, in 1959-60. It was around this time that the idea of a counterfactual theory of causation first took hold in Lewis's mind, as he declares in one of his later papers: 'My second paper in my first philosophy course defended a counterfactual analysis of causation. I've been at it, off and on, ever since' (Lewis 2004: 75). Lewis's Nachlass contains two such papers, 'On Causality and Natural Laws' and 'Particular and General Causal Claims', both dating from 1961, and written at Swarthmore. ${ }^{6}$ As Lewis's first publication on the topic quotes Hume, it is

\footnotetext{
${ }^{5}$ Lewis's Nachlass of as yet unpublished papers, student work, and extensive correspondence spanning about 40 years of his philosophical career, is held in the Firestone Library at Princeton University. As part of the three-year AHRC project grant 'The Age of Metaphysical Revolution: David Lewis and His Place in the History of Analytic Philosophy', I and my colleagues, Helen Beebee, Fraser MacBride, and Anthony Fisher, have been granted permission by Stephanie Lewis, David Lewis's widow and executrix, to publish our selection of philosophically significant work from the Nachlass.

${ }^{6}$ Thanks to Anthony Fisher for drawing my attention to this passage and the relevant student papers.
} 
quite possible that his undergraduate reading of Hume inspired the counterfactual theory. But Hume's doctrine that everything is loose and separate is not in evidence here. Among the postgraduate papers preserved in Lewis's Nachlass, there are none that concentrate on Hume, or on other philosophers of a Humean turn of mind such as Ramsey. And towards the end of his life, Lewis wrote to Galen Strawson - who denied that Hume was a Humean - that he, Lewis, lacked the historical knowledge to come to an informed view on Hume's own position (Lewis to Strawson, 23 June 1997). ${ }^{7}$

A more plausible source of Lewis's Humeanism is Quine, Lewis's PhD supervisor, whose course on Word and Object he attended at Harvard in 1963 (letter to Ruth Barcan Marcus, 19 April 1996), and whom he first approached in writing in the academic year 1964-5 with a thesis proposal on 'the tacit conventions of language' (Lewis to Quine, 9 February 1965). Lewis's proposal found favour with Quine, who agreed to supervise the thesis (Quine to Lewis, 10 February 1965). By contrast to Lewis, Quine had a solid grounding in Hume that went well beyond undergraduate perusal. He gave a lecture course on Hume at Harvard in the mid-1940s, whose content was of such interest that it was recently published (Quine 2003 [1946]), and has been the subject of several scholarly papers (Pakaluk 1989, Buickerood 2004). A noteworthy passage in it prefigures a sort of counterfactual theory of causation, even though Lewis's version pre-dates his association with Quine. Quine's passage notes that 'causation and prediction can be separated' with causation being an ontic necessary connection, and prediction based on constant conjunction (Pakaluk 1989: 448 n. 18). A lecture course produced some eighteen years before Quine and Lewis met might have been completely forgotten by the '60s. But Quine's published papers from the period surrounding his supervision of Lewis's thesis regularly show detailed engagement with Hume, mentioning him, for instance, while arguing against a first-philosophical justification of induction in 'Epistemology Naturalized' (p. 72; also see Raïd 2003).

Most tellingly, there is Quine's semi-popular paper 'Necessary Truth', dating from 1963, the year Lewis first came across him. In this paper, Quine defended at length Hume's dictum 'there are no necessary connections of matters of fact' (1976 [1963]: 71), that is, Humeanism. Quine took Hume's dictum to be expressing the thesis that there is no more to alleged necessary connections than generality or regularity. The adverb 'necessarily' is properly applied not to atomic sentences, but to conditionals linking descriptions of events: 'the point is, in all cases, to seek the necessity not in the separate matters of fact but in the connections between them' (1976 [1963]: 70). Subjunctive conditionals apparently dealing with dispositions and the like form apparent counter-examples to Quine's regularity analysis. 'Soluble' does not merely mean 'dissolves if put in water'- that open formula is vacuously satisfied by a lump of stone which always remains dry. According to Quine, such apparently problematic subjunctive conditionals can be analysed away. 'Soluble' really includes a covert reference to the chemical properties of the substance in question, a correct description of which accounts in non-subjunctive terms for its dissolving whenever it comes into contact with water. Quine's formulation of Hume's dictum involving 'matters of fact' is significant, because it means his position is not vulnerable to objections to Humeanism

\footnotetext{
${ }^{7}$ Thanks to Helen Beebee for drawing my attention to the letter to G. Strawson.
} 
which quibble over what 'distinct existences' are. In one central respect, Quine's version of Humeanism is more radical than Hume's. Hume distinguished matters of fact from relations of ideas, that is, logic and mathematics. According to him the only true necessity is logico-mathematical necessity. Quine saw no sharp distinction between the empirical, theoretical science, mathematics, and logic. So he concluded that all kinds of necessity, including the logical, are subspecies of natural necessity. All are in the final analysis no more than regularity (1976 [1963]: 74-76).

Quine's way of spelling out Hume's dictum is not identical to that of Lewis, whose formulations of Humeanism usually relied on possible worlds: 'we look to the Humean denial of necessary connections between distinct existences ... patching together parts of different possible worlds yields another possible world ... the principle is that anything can coexist with anything else, at least provided they occupy distinct spatiotemporal positions' (Lewis 1986a: 87-88; see also Lewis 2009: 208-209). Even though Quine's Humeanism and Lewis's are not identical, circumstantial evidence from both published and unpublished sources suggests that the idea of Humeanism came to Lewis via Quine, rather than Hume. Ramsey may have been a more minor influence on Lewis's mature Humeanism, as evinced by, for instance, Lewis's discussion of Ramsey's Humean views on natural laws (Lewis 1973: 73-74). But the lion's share of the evidence points to Quine as its principal source. Quine, unlike Lewis, was well-versed in Hume's thought and was, just around the time he and Lewis met, developing a version of Hume's dictum consonant with his own philosophical commitments. This likely inspired Lewis to develop a version suited to his own system years later.

\section{The Quinean Roots of Lewis's Humean Counterpart Theory}

Although in the quotation above, Lewis's Humeanism is expressed in terms of separating and rearranging the components of possible worlds, that way of putting things is metaphorical. Lewis did not believe that the same thing could appear in two distinct possible worlds. His official line on Humeanism deploys his counterpart theory. (In particular, it makes use of duplicates, a special case of counterparts (1986a: 87-89).) Lewis's counterpart theory is another component of his system which grew organically out of his interactions with Quine. It clearly bears the stamp of interaction with his former teacher. It is also another corrective to the misconception that Lewis was more like contemporary metaphysicians than like Quine. Lewis's mature counterpart theory, which takes modal judgements and essentialist predications to be inconstant and context-dependent, echoes Quine's mature view that we can make sense of essentialist discourse in terms of holding certain parts of a description fixed.

Evidence from the Nachlass reveals that Lewis began to believe in his possible worlds less than a year before 1 October 1968, when he wrote to Quine, 'up to about a year ago, I took for granted that possible worlds were entia non grata unless reduced to state descriptions, maximal consistent sets of sentences, or the like' (Lewis to Quine, 1 October 1968). He attributes his change of heart partly to the thought that possible worlds and sets are equally problematic posits, and partly to 'the counterpart paper, which I take 
to remove the difficulties about inter-world identity' (Lewis to Quine, 1 October 1968). The paper in question (Lewis 1968) began as an attempt to show that possible worlds could be fitted into a Quinean meta-ontology. Early Quine had not only dismissed modal ontology as anti-physicalist, but written off the very idea of a possibile as incoherent. Though not wholly dismissive of Barcan's (1947) syntactic treatment, during that period he categorically opposed interpreted modal logics, arguing that their characteristic posits, whether concepts or possibilia, suffered from a lack of clear criteria of identity (1948: 23). The problem is only exacerbated by Kripke semantics, with their proliferation of domains of discourse, intended to model possible worlds. A Kripke-style interpretation brings with it two kinds of quantifier, the pair ' $\square$ ' and ' $\nabla$ ' and the pair ' $\exists$ ' and ' $\forall$ '. The latter perform the function they perform in non-modal first-order theories, but the former range over possible worlds. Each world forms a domain of discourse for ' $\exists$ ' and ' $\forall$ ' to range over, its elements interpreted as objects contained within the worlds. By Quine's standards, this makes a mystery of how to translate modal theories into his canonical language of regimentation, and of the interpretation of trans-world identity statements. If there is no single unified domain of quantification, but multiple ones existing side by side, there is no obvious answer to the question whether an object in some world is identical to an object in another - the question Lewis, in his letter, refers to as 'inter-world identity'.

Counterpart theory provides principled answers both to the question of regimentation and to that of trans-world identity. Lewis translated away the appearance of a hierarchical ontology of worlds whose contents are only locally quantified over by letting ordinary firstorder quantifiers range over worlds as well as their contents, that is, their parts. The scope of our quantifiers is much wider than we normally assume, encompassing all of the modal pluriverse, but it is ordinary first-order quantification all the same. On his reading, it follows that two things located in distinct possible worlds are never identical, since they occupy different locations in the pluriverse. When we speak counterfactually of an individual, talking about what she might have been or done, we make covert reference to her counterparts, the individuals most similar to her in alternative possible worlds. Worlds and possibilia, though existing in distinct space-times, are simply physical objects with clear criteria of identity.

After 1968 Quine ceased to complain about the unintelligibility of possible worlds (Quine 1968). He admitted certain senses of 'possible world', like 'cosmic distribution of particles' as physicalistically kosher, though he continued to worry that 'this idea affords us no general way of equating sentences in real life' (1970: 4). While Lewis inherited a large amount of his philosophical presuppositions from Quine, in this case we see the student influencing the teacher's views. Quine, initially strongly anti-modal, gradually softened his stance on modal logic under the influence of Barcan Marcus during the '50s and '60s. He grudgingly admired Barcan's quantified modal logic, not interpreted in possible-world terms, and entirely free from use-mention confusions or anti-nominalistic posits, and she persuaded him that several of his anti-modal arguments were misguided (Janssen-Lauret 2015: 161). Yet until the late '60s, Quine still fervently maintained that there was no sense to be made of modal ontology, which Barcan Marcus, an inveterate nominalist, did not believe in (Janssen-Lauret 2015: 158-159). When we see Quine softening his stance on 
modal ontology specifically, from the year of Lewis's rebuttal onwards, the influence must have come from Lewis.

Still, Quine was nowise moved to countenance any modal ontology. He held on tightly to his extensionalism for the rest of his days, and was not much impressed with counterpart theory. 'What I object to in [intensions] is the use of possible worlds. And what I mainly object to in possible worlds is the counterpart relation' (letter to Lewis, 1 August 1974). His stated reason in that letter is that his three grades of modal involvement still apply. But several of the moves he made in 'Three Grades of Modal Involvement' (1976 [1953]) like the number of the planets argument, and the argument that modal logic implies an invidious Aristotelian essentialism - are among those made obsolete by Barcan Marcus' arguments. Yet part of Quine's anti-essentialist argument not only survived unscathed, but was gradually embraced, over the course of the '70s, by Lewis, who eventually settled on a profoundly anti-essentialist counterpart theory.

Quine opposed the third grade of modal involvement, quantification into modal contexts, because of its purported connection with what he called 'Aristotelian essentialism'. Quantified modal logic, Quine argued, forces us to divide an object's properties into the essential and the accidental, independently of either the context in which the question is raised or the object's theoretical role (Quine 1976 [1953]: 175-176). But no such division can sensibly be made, so we should abjure modal logic. Barcan Marcus was quick to point out that modal logic forces no such division upon us (Barcan Marcus 1967). What is striking from a twenty-first century point of view is that she does not contest Quine's main anti-essentialist claim, that a description-independent division of an object's properties into the essential and the accidental is senseless.

Modern metaphysicians are convinced that Quine's anti-essentialist arguments are obviously mistaken, and that their side has won the day. Nowadays the thesis that we can know an object's essential properties context-independently is known simply as 'essentialism', and so widely accepted among metaphysicians that it is frequently asserted without much argument. Laurie Paul, for example, writes, 'What objects are is determined by their modal properties, and these are determined in a context independent manner' (Paul 2006: 345). Brian Ellis writes that true essentialist claims 'are such that the thing to which reference is made, whether by name or by gesture, could not fail to have the property ascribed to it while still being the individual it is' (2001: 11). And Penelope Mackie writes, 'It is natural to think that it is a necessary condition for anything to be counted as a variety of essentialism that it conform to the principle that the status of an object's properties as essential or accidental to it is independent of the way in which the object is described or referred to' (2006: 3). Again, their attitude is ahistorical, especially so if they assume that Lewis was one of them in this regard. Although Mackie notes that Lewis was not, she nevertheless dismisses his view without argument and endorses the description-independence principle instead. But she and her fellow essentialists are wrong to do so.

Ahistorical attitudes which lead metaphysicians to write off Quine's view that modal attributions are context-dependent, and embrace essentialism instead, instill in those metaphysicians a false sense of security. A better sense of the history of twentieth-century 
philosophy reveals that their side never won the day. Quine's main anti-essentialist argument remains in force. Lewis's counterpart theory evolved to account for it, resulting in the doctrine of modal inconstancy (1986: 254). By the time Quine expressed his distaste for 'the' counterpart relation, implying that the relation is unique, Lewis had already admitted that the problem of personal identity forced him to 'revise my counterpart theory by providing for a multiplicity of counterpart relations' (1971: 203). ${ }^{8}$ Lewis must have assumed a unique counterpart relation in 1968; not only did he speak consistently of 'the' counterpart relation in that paper, but he could hardly have considered the 1971 introduction of a multiplicity of counterpart relations a revision if he had assumed a multiplicity before. Later versions of his counterpart theory are increasingly closely modelled on Quine's view that all modal attributions are context-dependent, arriving eventually at an explicit endorsement of full modal inconstancy. To see why, we must chart the evolution of Quine's anti-essentialist arguments.

The young Quine had thought of modal judgements as inextricably mired in analyticity. "The result of prefixing " $\square$ " to any statement is true if and only if the statement is analytic' (1947: 45). Early versions of his anti-essentialist arguments consequently present statements of the form ' $x$ is essentially $F$ ' as having an underlying form which attributes analyticity to sentences ascribing $F$-ness to $x$. Even if we grant that 'rationality is involved in the meaning of the word "man" while two-leggedness is not; but two-leggedness may at the same time be viewed as involved in the meaning of "biped" while rationality is not', Quine complained, the essentialist judgement cannot stand in isolation from such claims of analyticity: 'it makes no sense to say of the actual individual, who is at once a man and a biped, that his rationality is essential' (1951c: 22). But the mathematical cyclist argument is not given up after Quine ceases to describe modality as reducible to analyticity (Quine 1960: 199). The kernel of the argument is that essence only makes sense in context. Its 'Two Dogmas' incarnation stresses the negative claim that by just referring to the individual, without foregrounding certain salient properties, essentialist claims are difficult to make sense of. Later versions of the argument place increasing stress on the positive proposal that, given a description of an object, it is possible to hold fixed some of the predicates comprising that description, as though they were immutable, and let others vary. 'Certain properties of a thing or substance are under investigation, against a background of others that are not being questioned. The utility of this contrast, dependent again on the project of the moment, has doubtless nurtured the age-old belief in an eternal distinction between essence and accident. I part company with the essentialists and the modal logicians only when they accord these modes a place in the austere and enduring description of reality' (1986: 94).

Lewis's doctrine of modal inconstancy similarly makes essential and accidental predications relative to context. It is not just that there is no unique counterpart relation, because who or what is most similar to some actual individual in some alternative possible world is a vague matter; who your counterparts are also depends on the context in which the modal question is raised. Asking in isolation whether, for instance, Hillary Clinton

\footnotetext{
${ }^{8}$ For further details, see Beebee and MacBride 2015.
} 
could have been a man, or a black woman born to different parents, or a woman born to different parents in the nineteenth century, is just baffling. But raised in the context of a discussion on whether Clinton's career would have progressed more smoothly had she been male, or have faced even greater obstacles had she been black, or how she might have responded to the even more sexist nineteenth century, these questions make perfect sense (1986: 252). According to Lewis's account, the first question selects for male counterparts, the second for black female counterparts, and the third for nineteenth-century female counterparts. Essentialist accounts will generally have trouble accounting for all three of the above. Those which rely on the essentiality of origin, where Clinton's essence is to come from one particular pair of gametes produced by her exact biological parents, would struggle to make sense of any. And yet this kind of counterfactual scenario is very common in moral and political discourse. Lewis saw this, and neatly accommodated it by means of the huge modal ontology he was already committed to. According to Quine's Humean version of events, though, no modal ontology is necessary. All we need is our current theory, including its conditionals expressing natural regularities. We choose certain parts of its descriptions of the world and its inhabitants to hold fixed (for instance, those to do with the history, culture, and politics of the US, and the character, intelligence, and political interests of Hillary Clinton) and let others vary (for instance, Clinton's gender or ethnicity). We derive the consequences of this alternative, counterfactual theory. Against the scientific essentialists (like Ellis, quoted above) who hold that science must deal with essences, Quine counters that while science does contain a 'respectable vestige of essentialism [which] consists in picking out those minimum distinctive traits of a chemical, or a species, or whatever, that link it most directly to the central laws of the science' such characterisations are neither a priori nor analytic, but 'of a piece rather with the chemical or biological theory itself' (1976 [1972]: 52).

\section{Conclusion}

Aristotelian and a priori metaphysics, after being thrown into doubt by previous generations, has made a surprise come-back in recent years. Even more surprising is the content of the doctrines most contemporary metaphysicians consider uncontroversial: that the modal structure of the world, including what kinds of things could possibly co-exist, is fixed, knowable a priori, and completely separate from empirical enquiry, and that essentialism is both true and known pre-theoretically, a priori. At the same time metaphysics also has its vocal detractors, who doubt whether metaphysics of any sort is at all coherent. The current dissensus is due to our collective amnesia about our recent history. Sound historical work on the mid- to late twentieth century is needed break through this impasse. Historical investigation makes clear that the popular tale according to which Lewis is the champion of the new metaphysics, Quine its neo-pragmatist enemy, cannot stand. Lewis's system grew out of the application of the guiding principles of the empiricism of his teacher Quine. Both teacher and student were empiricist metaphysicians, finding a role for philosophical enquiry about the existence and nature of things in its interdependence with

the deliverances of the sciences. In particular, this applies to the cornerstone of Lewis's 
system, his Humeanism. This doctrine did not result from Lewis's reading of Hume, but from Quine, who defends it in a paper dated around the time he first met Lewis. Lewis's mature Humean counterpart theory is also Quinean in inspiration, a modal realist version of Quine's view that essence makes sense only in context. According to Quine we may hold fixed certain parts of the description of an object, counting them as essential for present purposes, letting others vary freely. Lewis takes over the view that essential attribution is context-dependent, explaining this in terms of different contexts selecting for different ranges of salient counterparts.

\section{ACKNOWLEDGEMENTS}

I am grateful to Stephanie Lewis for permission to access and quote from the Quine-Lewis correspondence and Lewis's student papers. Thanks are also due to Helen Beebee, Matti Eklund, Anthony Fisher, Gary Kemp, Nathan Kirkwood, Fraser MacBride, and Justin Mullins. This research was supported by the AHRC project grant 'The Age of Metaphysical Revolution: David Lewis and His Place in the History of Analytic Philosophy'.

\section{REFERENCES}

Ruth C. Barcan (1947) 'The Identity of Individuals in a Strict Functional Calculus of Second Order', Journal of Symbolic Logic, 12(1), 12-15.

Ruth Barcan Marcus (1967) 'Essentialism in Modal Logic', Noûs, 1(1), 90-96.

Ruth Barcan Marcus (1978) 'Nominalism and the Substitutional Quantifier', The Monist, 61(3), 351-362.

Helen Beebee and Fraser MacBride (2015) 'De re modality, essentialism and Lewiss Humeanism' in B. Loewer and J. Schaffer (eds.) The Blackwell Companion to David Lewis, New York: Blackwell.

Yemima Ben-Menahem (2005) 'Black, White and Gray: Quine on Convention', Synthese, 146(3), 245-282.

J. G. Buickerood (2004) 'Addenda to Quine on Hume' Eighteenth-Century Thought 2, 153163). Richard Creath (1990) Dear Carnap, Dear Van, University of California Press.

Walter Carnielli, Frederique Janssen-Lauret, and William Pickering (eds. and trs.) (under contract) The Significance of the New Logic: A Translation of O Sentido da Nova Logica, Cambridge University Press.

Brian Ellis (2001) Scientific Essentialism, Cambridge University Press.

Greg Frost-Arnold (2013) Carnap, Tarski, and Quine at Harvard: Conversations on Logic, Mathematics and Science, Open Court.

Peter Hylton (2007) Quine, Routledge.

Frederique Janssen-Lauret (2016) 'Committing to an Individual: Ontological Commitment, Reference, and Epistemology', Synthese 193(2), 583-604.

Frederique Janssen-Lauret (2015) 'Meta-Ontology, Naturalism, and the Quine-Barcan Marcus Debate', in Quine and His Place in History (ed. G. Kemp and F. Janssen-Lauret), Palgrave Macmillan, 146-167.

David Lewis, Student papers: 'On Causality and Natural Laws' (1961) and 'Particular 
and General Causal Claims' (1961). In David Lewis Papers, Firestone Library, Princeton University.

David Lewis, Letter to Quine, 9 February 1965. In David Lewis Papers, Firestone Library, Princeton University.

David Lewis, Letter to Quine, 1 October 1968. In David Lewis Papers, Firestone Library, Princeton University.

David Lewis (1971) 'Counterparts of Persons and Their Bodies', Journal of Philosophy, 68, 203-11.

David Lewis (1973) 'Causation', Journal of Philosophy, 70(17), 556-567.

David Lewis (1973) Counterfactuals. Basil Blackwell.

David Lewis (1983) Philosophical Papers, vol. I. Oxford University Press.

David Lewis (1986a) On The Plurality of Worlds. Oxford University Press.

David Lewis (1986b) Philosophical Papers, vol. II. Oxford University Press.

David Lewis (1993) 'Mathematics is Megethology', Philosophia Mathematica,1, 3-23.

David Lewis, Letter to Ruth Barcan Marcus, 19 April 1996. In David Lewis Papers, Firestone Library, Princeton University.

David Lewis, Letter to Galen Strawson, 23 June 1997. In David Lewis Papers, Firestone Library, Princeton University.

David Lewis (1999) 'Armstrong on Combinatorial Possibility', in Papers in Metaphysics and Epistemology, Cambridge University Press.

David Lewis (2004) 'Causation as Influence', in John Collins, Ned Hall, and L.A. Paul (eds.), Causation and Counterfactuals, MIT Press, 75-106.

David Lewis (2009) 'Ramseyan Humility' in D. Braddon-Mitchell and R. Nola (eds.), Conceptual Analysis and Philosophical Naturalism, MIT Press, 203-22.

E.J. Lowe (2006) The Four-Category Ontology. Clarendon Press.

Fraser MacBride and Frederique Janssen-Lauret (2015) 'Meta-Ontology, Epistemology, and Essence: On the Empirical Deduction of the Categories.' The Monist, 98(3), 290-302.

Fraser MacBride and Frederique Janssen-Lauret, 'Quinean Humility', in F. Janssen-Lauret (ed.) Quine, Structure, and Ontology, Oxford University Press, volume in development.

Penelope Mackie (2006) How Things Might Have Been: Individuals, Kinds, and Essential Properties Oxford University Press.

A.W. Moore (2012) The Evolution of Modern Metaphysics: Making Sense of Things, Cambridge University Press.

P. Mancosu (2008) 'Quine and Tarski on Nominalism', in D. Zimmerman (ed.) Oxford Studies in Metaphysics vol. 4, Oxford University Press.

L.A. Paul, (2006) 'In Defense of Essentialism', Philosophical Perspectives, 20, 333-372.

Michael Pakaluk (1989) 'Quine's 1946 Lectures on Hume' Journal of the History of Philosophy, 27(3), 445-459.

Huw Price (2009) 'Metaphysics after Carnap: The ghost who walks?' in D.J. Chalmers, D. Manley, and R. Wasserman (eds.), Metametaphysics, Oxford University Press, 320-46.

W.V. Quine (1934) 'Ontological Remarks on the Propositional Calculus', Mind, 43(172), $472-476$.

W.V. Quine (1939) 'Designation and Existence', Journal of Philosophy, 36(26), 701-709. 
W.V. Quine (1944) O Sentido da Nova Logica, Martins.

W.V. Quine (1947) 'The Problem of Interpreting Modal Logic', Journal of Symbolic Logic, $12(2), 43-48$.

W.V. Quine (1948) 'On What There Is', Review of Metaphysics, 2(5), 21-38.

W.V. Quine (1951a) 'On Carnap's Views on Ontology', Philosophical Studies, 2(5), 65-72.

W.V. Quine (1951b) 'Ontology and Ideology', Philosophical Studies, 2(1), 11-15.

W.V. Quine (1951c) 'Two Dogmas of Empiricism', Philosophical Review, 60, 20-43.

W.V. Quine (1957) 'The scope and Language of Science', British Journal for the Philosophy of Science, 8(29), 1-17.

W.V. Quine (1960) Word and Object, MIT Press.

W.V. Quine (1968) 'Propositional Objects', Critica, 2(5), 3-29.

W.V. Quine (1969) 'Epistemology Naturalised', in Ontological Relativity and Other Essays, 1966, Columbia University Press.

W.V. Quine, Letter to Lewis, 1 August 1974, In David Lewis Papers, Firestone Library, Princeton University.

W.V. Quine (1970) Philosophy of Logic, Prentice-Hall.

W.V. Quine (1974) The Roots of Reference, Open Court.

W.V. Quine (1976 [1939]) 'A Logistical Approach to the Ontological Problem', in Ways of Paradox, Harvard University Press.

W.V. Quine (1976 [1953]) 'Three Grades of Modal Involvement', in Ways of Paradox, 1966, Harvard University Press.

W.V. Quine (1976 [1963]) 'Necessary Truth', in Ways of Paradox, Harvard University Press.

W.V. Quine (1976 [1972]) 'Vagaries of Definition', in Ways of Paradox, Harvard University Press.

W.V. Quine, Letter to Lewis, 10 February 1965. In David Lewis Papers, Firestone Library, Princeton University.

W.V. Quine (1986) 'Reply to Herbert G. Bohnert', in Hahn and Schilpp (eds.) The Philosophy of W.V. Quine, 1986, Open Court.

W.V. Quine (2003 [1946]) 'Lectures on Hume', in J. G. Buickerood, (ed.) EighteenthCentury Thought 1, 171-254

W.V. Quine (under contract [1944]) The Significance of the New Logic, in Carnielli, JanssenLauret, and Pickering (eds.), under contract.

W.V. Quine (1990) Pursuit of Truth, Harvard University Press.

Layla Raïd (2003) 'L'identité de l'objet : l'héritage humien de Quine', Revue de métaphysique et de morale, 38, pp. 181-197.

Gideon Rosen (2013) 'Quine and the Revival of Metaphysics' in G. Harman and E. Lepore (eds.), A Companion to W.V.O. Quine, Blackwell, 552-570.

Peter Simons (2013) 'Metaphysics in Analytic Philosophy' in M. Beaney (ed.) Oxford Handbook of the History of Analytic Philosophy, Oxford University Press, 709-28.

Tuomas Tahko (2011) 'In defence of Aristotelian metaphysics' in Contemporary Aristotelian Metaphysics, Cambridge University Press. 
Timothy Williamson (2014) 'How did we get here from there? The transformation of analytic philosophy', Belgrade Philosophical Annual, 27, 7-37. 